\title{
EISENOS TRENIRUOKLIO „EIK“ NAUDOJIMO GALIMYBĖS SENYVO AMŽIAUS ASMENIMS PO GALVOS SMEGENU KRAUJOTAKOS SUTRIKIMO
}

\author{
Milda Žukauskiené $\dot{1}^{1}$, Laimutė Samsoniene் $\dot{e}^{1,2}$ \\ ${ }^{1}$ Vilniaus kolegijos sveikatos priežiūros fakultetas, \\ ${ }^{1,2}$ Vilniaus universiteto Medicinos fakulteto Sveikatos mokslu institutas
}

Raktažodžiai: eisenos treniruoklis, eisena, pusiausvyra, galvos smegenų insultas, reabilitacija.

\begin{abstract}
Santrauka
Svarbiausia treniruoklių savybe - universalumas, patikimumas ir plačios naudojimo galimybès. Straipsnyje aptariamas eisenos treniruoklio EIK pritaikomumas ir naudojimo galimybės senyvo amžiaus neigaliesiems. Tyrimo tikslas - ivvertinti treniruoklio EIK naudojimo galimybes asmenims, patyrusiems galvos smegenų kraujotakos sutrikimą, parengti praktines rekomendacijas. Veiklos tyrime taikyti kokybiniai ir kiekybiniai tyrimo metodai: ekspertų apklausa, medicininių dokumentų analizè, testavimas (goniometrija, raumenų jẻgos vertinimas, $10 \mathrm{~m}$ èjimo; 6 min. ejjimo testai ir kt.), filmavimas, fotografavimas, statistinè duomenų analizè. Tyrimo rezultatai: eisenos lavinimo užsièmimai su EIK ženkliai pagerino visų tiriamujų nueinamą atstumą $(\mathrm{p}<0,05)$. Visų tiriamųų rezultatai kito nuosekliai. Ilgejant einamam atstumui, ilgejo nueitas atstumas iki pirmo sustojimo. Nustatyta, kad treniruoklis EIK turi didesnį teigiamą poveikį paciento liemens kontrolei, gerina liemens, pečiu juostos, nugaros raumenų funkciją, lavina èjimą, padeda atlikti taisyklingo ejjimo judesius, tiriamieji jaučiasi saugiau, neribojami jų viršutinès kūno dalies judesiai. Treniruoklis EIK tiriamiesiems, patyrusiems galvos smegenų insultą, yra tinkama aktyvinimo ir vertikalizavimo priemone, tačiau ši priemonè turi būti tikslingai individualizuojama pagal paciento poreikius.
\end{abstract}

\section{Ivadas}

Pasaulio sveikatos organizacija (PSO, 1972) reabilitaciją apibrèžia kaip kompleksišką medicininių, socialinių, profesinių ir juridinių priemonių taikymą, siekiant atkurti funkcinị reabilituojamo asmens aktyvumą [1]. Holistinis požiūris lemia, kad i žmogų žiūrima kaip ị visumą, sprendžiamos ne tik jo sveikatos, bet ir profesinès veiklos bei socialinės problemos. Vienas pagrindinių reabilitacijos uždavinių - atkurti asmens savarankiškumą, kuriam ypač svarbi èjimo funkcija. Ji gali būti sutrikdoma po įvairių traumų (kaulų lūžiai, raiščių patempimai), operacijų (sąnarių keitimo operacijos), o sudètingesniais atvejais - po galvos smegenų insulto, traumos, nugaros smegenų sužalojimo ar kitų priežasčių. Tada ejimo funkcijos lavinimas ir (ar) atgavimas tampa svarbiu neuroreabilitacijos tikslu. Naujų technologijų kūrimo ir panaudojimo galimybių paieškos yra aktualios, siekiant maksimalaus pakenktų judejjimo funkcijų atgavimo pacientams, kuriems dèl įvairių priežasčių sutriko eisena, koordinacija ir pusiausvyra. Viena iš judesių valdymo ir atgavimo teorijų teigia, kad judesiai gali būti atkuriami pasitelkiant nuolatos kartojamą, ị užduotị orientuotą pasikartojantị veiksmą, t.y. èjimo funkcijos atgavimo atveju - reikètu pastoviai treniruoti taisyklingą eiseną [2, 3]. Eisenos treniruokliai, kuriuose pacientas būtų vertikalizuojamas, jaustųsi saugus, galètų nevaržomai atlikti ne tik ejimui būdingus, bet ir kitus judesius, lavinti pusiausvyrą ir koordinaciją, puikiai tiktų siekti šio tikslo. Pastaraisiais dešimtmečiais atlikta daug mechanikos tyrimų, nagrinejjančių robotizuotų ejjimo treniruoklių naudojimą reabilitacijos metu [4]. Lietuvoje $2014 \mathrm{~m}$. sukurtas pirmasis, o $2017 \mathrm{~m}$. pristatytas naujas, patobulintas unikalus eisenos treniruoklio EIK modelis, skirtas lavinti su ejjimu susijusius judesius, saugiai vertikalizuoti, lavinti pusiausvyrą, koordinaciją bei kitas funkcijas [5]. Šio reabilitacijai skirto treniruoklio konstrukcija sudaryta iš mechaninių ịrenginių, kurių panaudojimas gali būti reguliuojamas, priklausomai nuo paciento sąmoningų pastangų, reabilitacijos eigos bei sudarytos reabilitacijos programos. Su šiuo treniruokliu atlikti tyrimai [6-8] ịrode jo taikymo efektyvumą galvos smegenų insultą patyrusiems pacientams.

Tyrimo tikslas - ivvertinti treniruoklio EIK naudojimo galimybes asmenims po galvos smegenų kraujotakos sutrikimo bei parengti rekomendacijas. 


\section{Tyrimo medžiaga ir metodai}

Veiklos tyrimas atliktas 2017 metais pagal iš anksto apibrèžtus ir numatytus kriterijus, miesto reabilitacijos ir slaugos centre. Atrankos procedūra - tirti asmenys su liekamaisiais reiškiniais po galvos smegenų kraujotakos sutrikimo. Dalyvauti tyrime pacientai buvo kviečiami asmeniškai ir tik gavus jų sutikimą, įtraukiami ị tiriamujų grupę. Informacija iš asmens medicininių dokumentų buvo renkama vadovaujantis LR asmens duomenų teisinès apsaugos įstatymo nuostatomis, buvo kaupiami duomenys taip, kad pagal juos negalima būtų identifikuoti asmens.

Atrankos kriterijai:

- pacientai, patyrę galvos smegenų insultą;

- $\quad$ stabili širdies ir kraujagyslių sistemos būklè;

- gebantys suprasti tyrimo užduotị ir žodines komandas (Protinès būklès mini tyrimas (MMSE) ne mažiau kaip 20 balų) [9];

gebantys išlaikyti pusiausvyrą sėdint bei persikelti su minimalia ar vidutine pagalba nuo lovos (Berg pusiausvyros testas ne mažiau kaip 21 balas);

- gebantys savarankiškai apsitarnauti (Barthel indeksas ne mažiau kaip 60 balų).

Pacientai, neatitinkantys bent vieno atrankos kriterijaus, ị tyrimą buvo neitraukiami. Tyrimą ribojo ir tai, kad dalyvaujant neigaliesiems, galutine tiriamujų imtis yra sunkiai prognozuojama, jautri ir kintanti. Ne visi pirminiuose tyrimo protokoluose numatyti tyrimo metodai galèjo būti pritaikyti tiriamajai populiacijai: tai ribojo asmenų funkcinè ir psichinè būklè bei kitos tyrimo atlikimo sąlygos.

Pradiniame etape pagal minètus kriterijus buvo atrinkti 35 tiriamieji, tačiau 24 surinko mažiau kaip 20 balų pagal MMSE todèl liko 11, iš kurių 7 sutiko dalyvauti tyrime. Tyrimo eigoje viena pacientė mirè, kita išvyko pasibaigus sutarčiai su TLK. Liko 5 tiriamieji. Pradiniame tyrimo etape dalyvavusių pacientų amžiaus vidurkis $82 \pm 10$ metų: 2 vyrai ir 3 moterys. Atliktas EIK treniruoklio pritaikomumo ekspertinis vertinimas. Siekta aprobuoti inovatyvią metodiką, parengiant praktines rekomendacijas treniruoklio kūrejams ir gamintojams. Ekspertai išbandè vaikštynę, pabandę naudotis ją prisitaikè sau patys ar padedami, todèl vaikštynès saugumas buvo patikrintas ir garantuotas. Medicininių dokumentų analizė atlikta siekiant išsiaiškinti išsamią ligos anamnezę ir susikurti labai aiškų pacientą apibūdinantị paveikslą.

Tiriamujų orientacija laike ir vietoje, naujos informacijos įsiminimas (fiksacinė atmintis), dèmesys, skaičiavimo, kalbos ir konstrukciniai gebèjimai vertinti protinès būklès mini tyrimu (MMSE) [10]; judesių sutrikimai vertinti Motricity indeksu (MI); liemens kontrolès testu (TCT) buvo tiriami keturi liemens judesių aspektai; raumenų jèga buvo matuojama rankiniu dinamometru (BASELINE mechanical

push-pull dynamometer model 12-0303). Nueitas atstumas bei funkcinis pajègumas procedūros metu vertintas 6 minučių ejjimo testu [11]. Šio tyrimo metu jis buvo atliekamas su eisenos treniruokliu EIK (2 pav.). Esminis kriterijus yra nueitas atstumas per $6 \mathrm{~min}$ ir atstumas, testavimo metu nueitas iki pirmo sustojimo. Dèl saugumo stebimas ir širdies susitraukimo dažnis (ŠSD). Pradinis ŠSD fiksuojamas pacientui atvykus i tyrimo vietą. Tyrimo atlikimas: tiriamasis itvirtinamas eisenos treniruoklyje EIK, ratukai fiksuojami krypties padetyje „fixed“. Kai pacientas pradeda eiti, ijungiamas laikmatis, stebimas pirmas nueitas atstumas nesustojant ir bendras nueitas atstumas. Praejjus šešioms minutèms, vèl iškart matuojamas ir registruojamas ŠSD. Jei įtariami fizinio krūvio netoleravimo požymiai, ŠSD matuojamas ir tyrimo eigoje. Gauti duomenys registruojami kineziterapijos procedūrų stebejjimo protokole, testas atliekamas kiekvieno susitikimo pradžioje. Rezultatai nediferencijuojami pagal konkretų vertinimą (gerai-blogai), svarbiausias kriterijus yra bendras nueitas atstumas ir atstumas iki pirmo sustojimo. ŠSD matuojamas manualiai (prie riešo), todèl šiuo atveju tai nèra svarbus rodiklis. Testo vykdymas filmuojamas, medžiaga naudojama vaizdo analizei.

Laikysena vertinta fotometrijos būdu, naudojant išmaniosios aplikacijos programą Posture Screen Mobile (www. PostureAnalysis.com). Fotografuojama dviejose padètyse: iš priekio ir iš šono. Eisenos analizè atlikta Kinovea programa (https://www.kinovea.org). Filmuojamos 2-3 žingsnio fazès. Filmavimo stabilumui užtikrinti, vaizdo kamera statoma ant stovo. Parenkamas tinkamas filmavimo aukštis ir kampai. Tiriamieji patalpinami ị eisenos treniruoklị ir prašomi normaliu ejimo tempu eiti 2-3 žingsnio fazes (pacientas filmuojamas po vieną kartą iš dešinès pusès ir iš priekio). Filmuota medžiaga perkeliama ị kompiuterị, analizuojama naudojant lètėjimo funkciją, kad būtų galima tiksliau pažy-

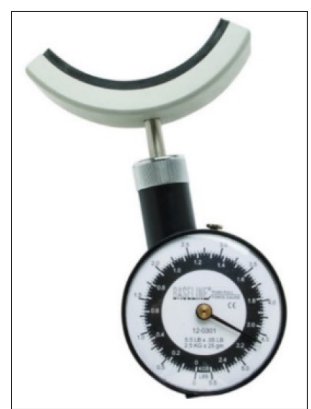

1 pav. Rankinis dinamometras ,BASELINE model 12-0303“ (30 kg) raumenų jëgai išmatuoti. Šaltinis: https://www:fab-ent. com

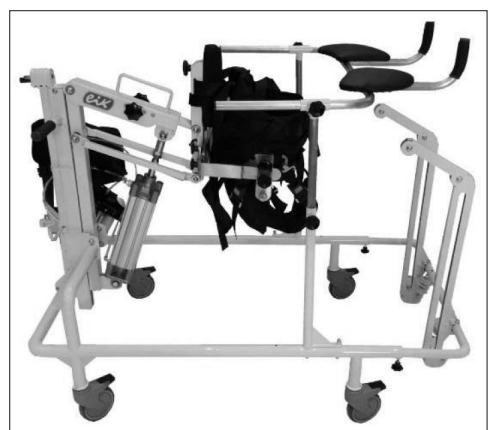

2 pav. Eisenos treniruoklis EIK Śaltinis: www.eik-lt.eu 
mèti, kada prasideda ir baigiasi žingsnių fazès. Kai paciento judesio atlikimas atitinka kulno atramos (angl. stance phase heel contact), amortizacijos (angl. stance phase heel rise) ir atsispyrimo (angl. preswing phase toe off) fazes, spaudžiama pauzès nuoroda. Pasirenkama kampų piešimo funkcija, analizuojami sąnariai pažymimi taškais, parenkamos spalvos ir vedamos linijos ị distalųji ir proksimalųji pasirinkto sąnario galus. Programa rodo ir registruoja judesio amplitudès kampu parametrus. Išsaugomos nuotraukos su kampų parametrais. Kai judesio atlikimas trijose fazèse išanalizuotas su kampu piešimo funkcija, duomenys suvedami į Microsoft Office Excel lenteles.

Vienas iš planuotų tyrimo metodų - elektromiografijos (EMG) tyrimas specialiu prietaisu [12]. EMG signalo užrašymui ir apdorojimui keliami tam tikri reikalavimai (kuo geresnè signalo kokybė ir kuo mažiau iškraipytas signalas). Šio metodo taikymą antrojoje tyrimo dalyje ribojusios priežastys:

O judesio artefaktai ir nuolatinè dedamoji. Tai triukšmas, sukeliamas elektrodams judant ant odos. Priešingai nei registruojant EKG, kai pacientas prašomas pabūti ramiai, EMG reikalingas judesys, raumenų susitraukimas. Siekiant sumažinti ši artefaktą, reikalingas specialus odos paruošimas. Be to, riebalai, prakaitas ir negyvos odos ląstelès didina viršutinio odos sluoksnio impedansą, todèl susidaro nuolatinè dedamoji [13]. Siekiat išvengti šio triukšmo, be naudojamu ịvairių filtrų ir signalo stiprintuvų, elektrodai turi būti klijuojami ant švarios, depiliuotos odos ir negali būti pridengti drabužiais. Šios sąlygos buvo neịmanoma igyvendinti, tiriamiesiems nesutikus vaikščioti koridoriumi apnuoginta apatine kūno dalimi;

O raumenų biosignalų kryžiavimasis. Tai reiškinys, kai registruojant vieno raumens signalą, pajudinus šalia esantị raumeni, užfiksuojamas ne to raumens signalas arba

1 lentelè. Tiriamujų èjimo funkcijos vertinimo rezultatai (6 min ejjimo ir $10 \mathrm{~m}$ ejjimo testai)

* spalva žymimas rezultato pageréjimas

\begin{tabular}{|c|c|c|c|c|c|c|c|c|c|}
\hline \multirow[b]{2}{*}{$\cdot \frac{\pi}{\frac{\pi}{J}}$} & \multirow[b]{2}{*}{ 湑 } & \multirow[b]{2}{*}{ 点 } & \multicolumn{2}{|c|}{$\begin{array}{l}6 \text { min èjimo } \\
\text { testas (m) }\end{array}$} & \multicolumn{2}{|c|}{$\begin{array}{c}10 \mathrm{~m} \text { èjimo testas } \\
\text { I testavimas }\end{array}$} & \multicolumn{2}{|c|}{$\begin{array}{c}10 \mathrm{~m} \text { èjimo testas } \\
\text { II testavimas }\end{array}$} & \multirow[t]{2}{*}{ Pastabos } \\
\hline & & & I & II & \begin{tabular}{|l|} 
paciento \\
pasirinktu \\
greičiu
\end{tabular} & $\begin{array}{l}\text { didesniu } \\
\text { greičiu }\end{array}$ & $\begin{array}{l}\text { paciento } \\
\text { pasirinktu } \\
\text { greičiu }\end{array}$ & $\begin{array}{l}\text { didesniu } \\
\text { greičiu }\end{array}$ & \\
\hline A1 & 83 & $\mathrm{~V}$ & 119 & $162 *$ & $0,228 \mathrm{~m} / \mathrm{s}$ & \multirow{5}{*}{$\begin{array}{l}\text { Pacien- } \\
\text { tams ne- } \\
\text { pavyko } \\
\text { eiti di- } \\
\text { desniu } \\
\text { greičiu }\end{array}$} & $0,389 \mathrm{~m} / \mathrm{s} *$ & $0,489 \mathrm{~m} / \mathrm{s}$ & \\
\hline A2 & 70 & V & 109 & 157 & $0,198 \mathrm{~m} / \mathrm{s}$ & & $0,339 \mathrm{~m} / \mathrm{s}^{*}$ & $0,411 \mathrm{~m} / \mathrm{s}$ & \\
\hline A3 & 92 & M & 94 & $\mathrm{~N}$ & $0,295 \mathrm{~m} / \mathrm{s}$ & & $\mathrm{N}$ & $\mathrm{N}$ & $\begin{array}{l}\text { Dėl neaiškios kilmès } \\
\text { kojos skausmų ir tir- } \\
\text { pimo }\end{array}$ \\
\hline A4 & 81 & M & $\mathrm{N}$ & $\mathrm{N}$ & $\mathrm{N}$ & & $\mathrm{N}$ & $\mathrm{N}$ & $\begin{array}{l}\text { Dèl trigalvio žasto } \\
\text { raumens sumušimuo }\end{array}$ \\
\hline A5 & 84 & M & 86 & $\mathrm{~N}$ & $0,257 \mathrm{~m} / \mathrm{s}$ & & $\mathrm{N}$ & $\mathrm{N}$ & $\begin{array}{l}\text { Dèl komplikacijų } \\
\text { išvežta ị ligoninę } \\
\text { pacientė mirè }\end{array}$ \\
\hline
\end{tabular}

iškraipoma bendro signalo amplitudè. Norint išvengti šio artefakto, reikia tinkamai parinkti elektrodų dydį ir atstumus tarp elektrodų (elektrodų išdèstymas išilgai raumens skaidulų padeda išvengti kitų raumenų signalo). Siekiant i̇gyvendinti šią sąlygą, elektrodus reikejjo klijuoti kūno vietoje, kurioje užtikrinamas geriausias raumens susitraukimas (motorinis taškas). Reikejjo rasti kiekvieno planuojamo testuoti raumens ( $m$. gluteus med/max, $m$. rectus femoris, $m$. iliopsoas, $m m$. hamstrings; $m$. tibialis anterior, $m$. gastrocnemius ( $m$. triceps surae)) motorini tašką. Tai buvo bandoma padaryti prietaiso Cefar Compex Physio 5 (stimuliatorius, skirtas naudoti profesionalams raumenų stimuliacijai, jonoforezei ir denervacijos gydymui) ir jo motorinio taško ieškiklio pagalba. Tiriamiesiems ši procedūra buvo skausminga, vieni negalejo atsigulti ant pilvo, kiti - ant šono ir pan., todèl tyrimo atlikti nepavyko.

Galima teigti, kad mūsų tyrimo sąlygomis (tiriamasis kontingentas, jų fizinè ir funkcinè būklè, amžius, aplinka, kiti veiksniai) EMG tyrimas asmenims, patyrusiems galvos smegenų insultą, nebuvo tinkamas.

\section{Rezultatai ir jų aptarimas}

Vertinant 10 metrų ejimo rezultatus, nustatyta, kad pirmojo vertinimo metu 5 asmenys įveike šį testą savo pasirinktu greičiu. Jų greičio vidurkis $0,2445 \mathrm{~m} / \mathrm{s}$. Ejjimas nurodytu greičiu nebuvo vertintas, nes tiriamiesiems nepavyko eiti greičiau. Vienam tiriamajam, nesugebejjusiam savarankiškai eiti, testas neatliktas. Po pirmojo vertinimo tiriamieji jautèsi laisviau, nes susipažino su treniruokliu EIK, panoro vykti ị salę kineziterapijos procedūrai, ejjimas neprovokavo dusulio. Po dviejų savaičiu kartotini 10 metrų èjimo testą atliko 2 tiriamieji, nes vienas tyrimo dalyvis buvo hospitalizuotas dèl pneumonijos, kitam dèl kritimo diagnozuotas dešinès rankos trigalvio raumens sumušimas, ranka ịtvare, negali remtis dešiniu dilbiu ị atramą, nes skausminga, o trečiasis skundėsi kojų silpnumu ir atsisaké toliau dalyvauti tyrime. Dviejų atlikusių tyrimą tiriamųų rezultatai pagerejo. Vieno ejjimo greitis pasirinktu tempu pagerejo $0,161 \mathrm{~m} / \mathrm{s}$, o kito $0,141 \mathrm{~m} / \mathrm{s}$. Šie du tiriamieji po dviejų savaičių kineziterapijos procedūrų pajègé iveikti 10 metru atstumą ir nurodytu tempu - vieno rezultatas $0,485 \mathrm{~m} / \mathrm{s}$, o kito $0,411 \mathrm{~m} / \mathrm{s}$.

Prieš atliekant 6 min èjimo testą buvo išmatuotas koridoriaus 
ilgis (43 metrai). Tiriamasis saugiai vertikalizuotas eisenos treniruoklyje EIK prieš pažymètą liniją, ratukai fiksuoti ejjimo kryptimi. Pradedama tada, kai tiriamojo péda kerta pradžios liniją. Laikas fiksuojamas chronometru. Praejus šešioms minutems, stebimas tiriamojo nueitas bendrasis atstumas. Vidutinis nueitas 5 tiriamujų atstumas 102 metrai. Po dviejų savaičių likus dviems tiriamiesiems ir įvertinus 6 min ejjimo rezultatus, vidutinis nueitas atstumas buvo 159,5 metro: vieno tiriamojo rezultatas pagerèjo 43 , kito - 48 metrus. Apibendrinti tyrimo rezultatai pateikiami 1 lenteleje. Tyrimo rezultatai parodè, kad 2 pacientų 6 min èjimo testo (m) rezultatai pagerèjo; 10 metrų èjimo testo rezultatai pasirinktu greičiu taip pat pagerèjo, o didesniu greičiu jie ejjo 0,4 $\mathrm{m} / \mathrm{s}$ greičiau, kai pirmo testavimo apskritai negalejjo atlikti.

Laikysena vertinta Posture Screen programa iš priekio ir šono, stovint treniruoklyje EIK ir su aukšta vaikštyne. Antrasis vertinimas atliktas po 2 savaičių, per kurias tiriamiesiems buvo taikyta kineziterapija ir treniruojamas ejjimas su eisenos treniruokliu EIK. Pirminiame laikysenos vertinime (P) dalyvavo 3 tiriamieji, kurie po dviejų savaičių antrą kartą vertinti nebuvo. Abu vertinimai atlikti tiriamiesiems A1 ir A2. A1 laikysenos iš priekio vertinimo rezultatai pateikti 2

2 lentelè. A1 laikysenos iš priekio vertinimas, stovint EIK treniruoklyje

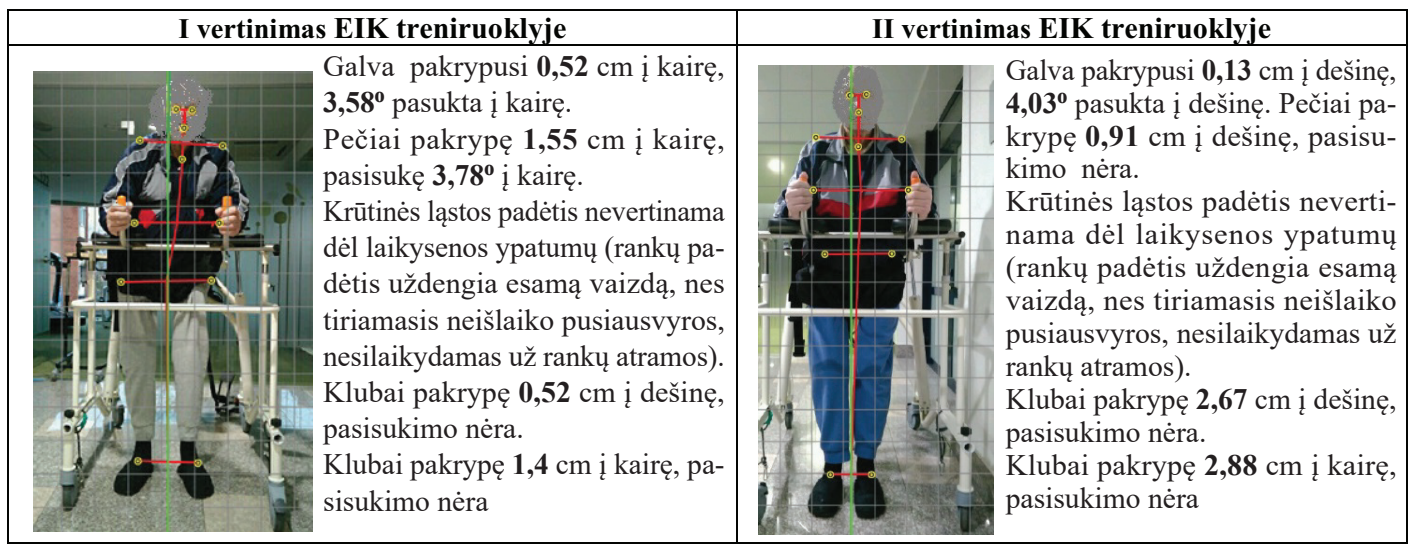

3 lentelè. A1 laikysenos vertinimas iš priekio vaikštynèje

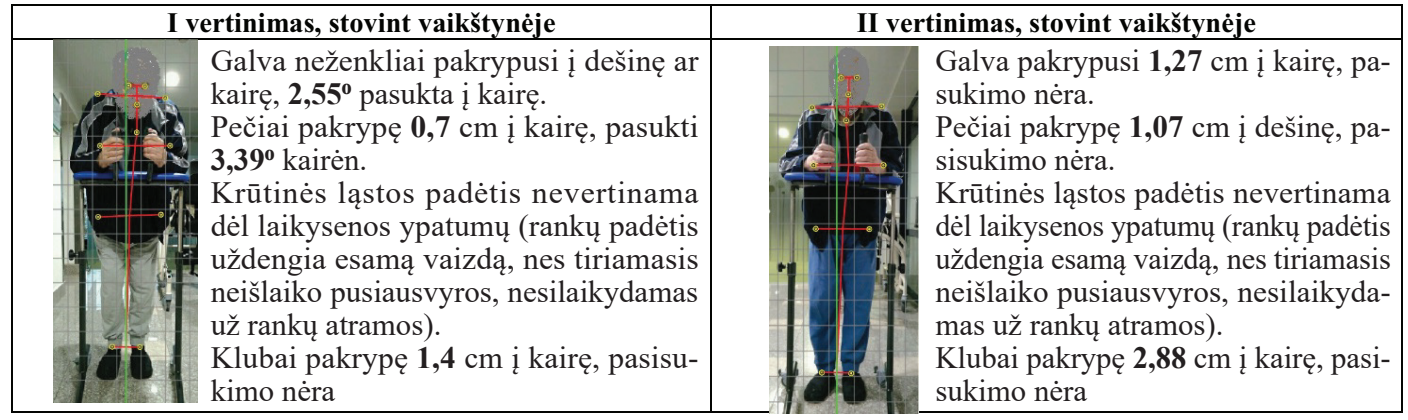

4 lentelè. A1 laikysenos vertinimas iš šono EIK treniruoklyje

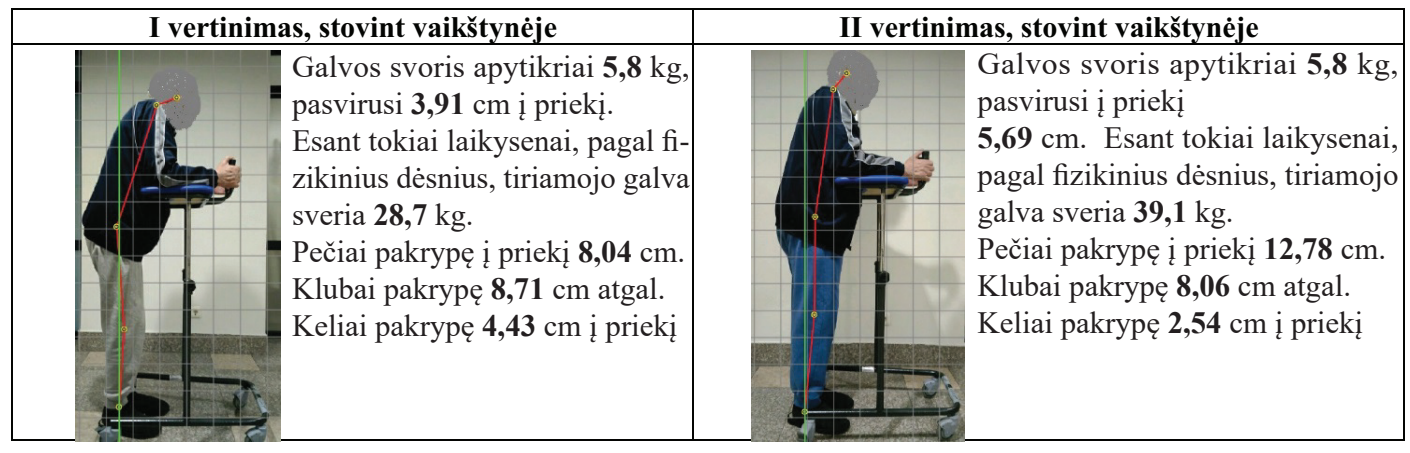


lentelèje. Po kineziterapijos procedūrų ir èjimo treniruočių su treniruokliu EIK, II vertinimo metu nustatytas nedidelis galvos pakrypimas ne į kairę, kaip I vertinime, o ị dešinę, išnykęs pečiu pakrypimas, tačiau klubų pakrypimas po procedūrų padidejjo 80 procentų.

A1 laikysenos iš priekio stovint vaikštynejje rezultatai parodyti 3 lentelejje. II vertinimo metu nenustatytas galvos ir pečių lanko pasukimas, kaip prieš tyrimą I vertinimo metu, tačiau klubai labiau pakrypę ị dešinę (ne 80 proc., kaip tre- niruoklyje EIK, o 51 proc.).

Po procedūru ịvertinus A1 laikyseną iš šono EIK treniruoklyje, nustatyta, kad galvos pasvirimas ị prieki padidèjo 31 proc., padidejo ir galvos svoris kūno laikysenai, tačiau kelių pakrypimas ị priekị sumažèjo 42,6 procento (4 lentelè).

Laikysenos vertinimas A1 iš šono vaikštynëje prieš tyrimą ir po jo parodytas 5 lentelëje. II vertinimo metu, skirtingai nei EIK treniruoklyje, nustatytas galvos svorio laikysenai sumažèjimas 15 proc., pasvirimo ì priekị sumažèjimas 17 proc., pečių lanko ì priekị pakrypimo sumažejjimas 46 proc.,

5 lentelè. A1 laikysenos vertinimas iš šono vaikštynèje

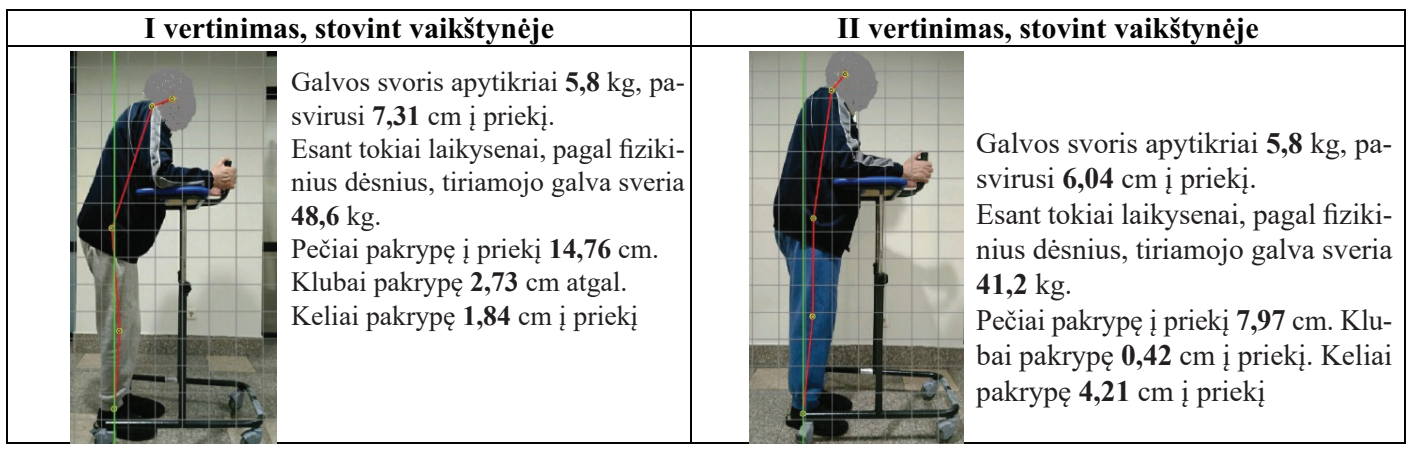

6 lentelè. A2 laikysenos vertinimas iš priekio, stovint EIK treniruoklyje

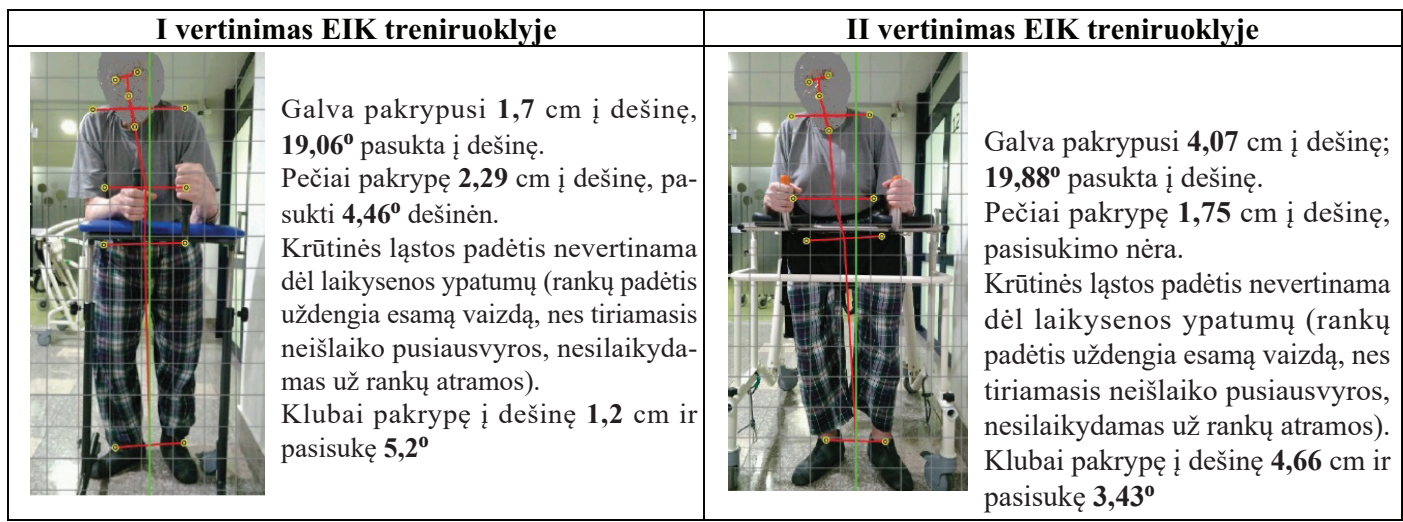

7 lentelè. A2 laikysenos vertinimas iš priekio, stovint vaikštynejje

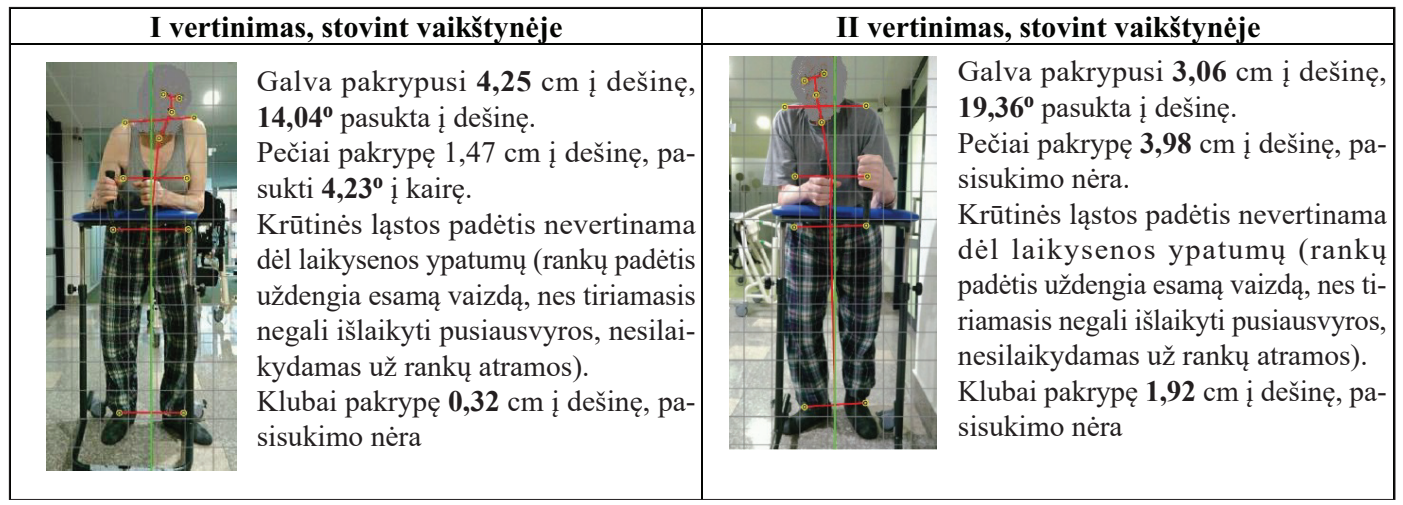


tačiau keliai vaikštynèje pakrypo ì priekị 56 proc. labiau, nei EIK treniruoklyje (sumažèjo).

Lyginant laikyseną iš šono stovint EIK treniruoklyje ir vaikštyneje, matoma, kad treniruoklyje visi laikysenos parametrai yra geresni tiek pirmojo, tiek antrojo vertinimo metu. Vis dèlto, kai kurių tiriamojo rezultatų treniruokliu EIK ir vaikštyne, palygintų tyrimo pradžioje ir po dviejų savaičių, regresuojantys pokyčiai galèjo būti dèl dviejų priežasčių: 1) fotografuota treniruoklyje, o po to - su aukšta vaikštyne, todèl tikètina, kad tai turèjo įtakos taisyklingesnès laikysenos rezultatams su aukšta vaikštyne; 2) tyrime dalyvavo tiriamojo dukra, tai galèjo turèti reikšmès, nes tiriamasis jaudinosi, buvo blaškomas jo dèmesys.

A2 laikysenos vertinimas iš priekio EIK treniruoklyje prieš ir po procedūrų parodytas 6 lentelejje. Po procedūrų nustatėme didesni galvos nuokrypi i dešinę, tačiau pečiai ị dešinę buvo pakrypę mažiau kaip 23 proc. ir išnykęs buvęs pasukimas; klubai buvo pakrypę labiau po procedūrų, tačiau pasisukimas sumažejęs 34 procentais.

Tyrimo metu iqvertintos A2 laikysenos iš priekio stovint vaikštyneje rezultatai parodyti 7 lenteleje. Po procedūrų, skirtingai nei EIK treniruoklyje, nustatytas galvos nuokrypio i dešinę sumažèjimas 28 proc., tačiau jos pasukimas ị dešinę padidèjo 27 proc.; pečių lanko pakrypimas padidèjo 63 proc., pasukimas ị kairę išnyko, klubų pakrypimas į dešinę padidejo 67 procentais.

Aukštoje vaikštynèje stovinčio tiriamojo laikysenos pokyčiai matomi, tačiau fotometrijos programa Posture Screen teigiamų pokyčių neparodè.

Vertinant vaikštynejje stovinčio A2 tiriamojo laikyseną

8 lentelè. A2 laikysenos vertinimas iš šono, stovint EIK treniruoklyje ir vaikštynèje

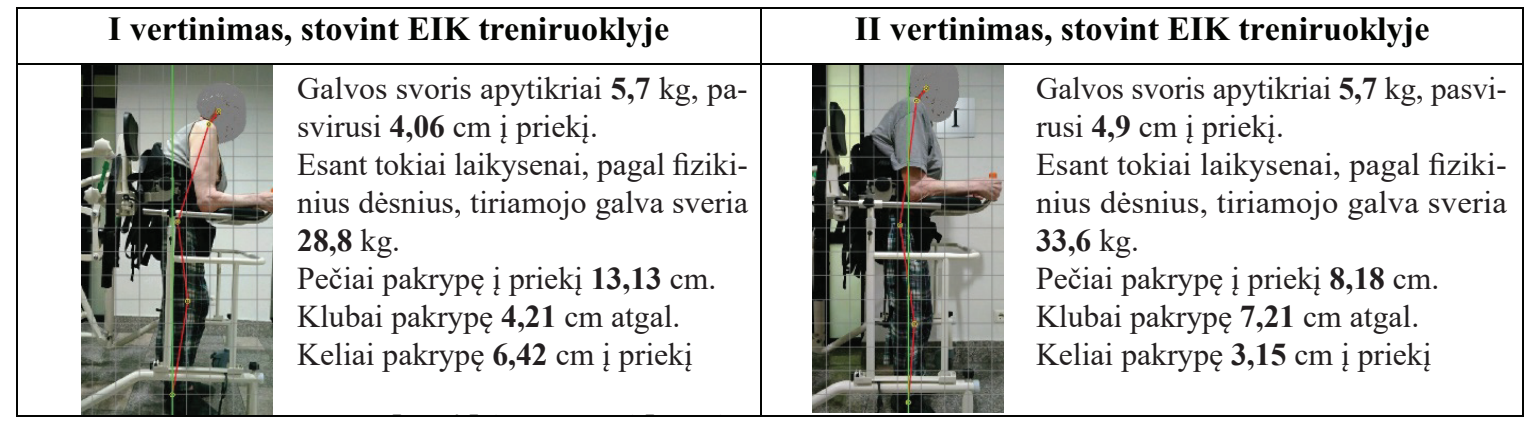

\begin{tabular}{|c|c|c|}
\hline I vertini & mas, stovint vaikštynėje & II vertinimas, stovint vaikštynèje \\
\hline$\prod_{-1}$ & $\begin{array}{l}\text { Galvos svoris apytikriai } \mathbf{5 , 7} \mathrm{kg} \text {, pa- } \\
\text { svirusi } \mathbf{7 , 3 1} \mathrm{cm} \text { ị priekị. } \\
\text { Esant tokiai laikysenai, pagal fiziki- } \\
\text { nius dėsnius, tiriamojo galva sveria } \\
\mathbf{4 7 , 3} \mathrm{kg} \text {. } \\
\text { Pečiai pakrypę ì priekị } \mathbf{1 3 , 5} \mathrm{cm} \text {. } \\
\text { Klubai pakrypę } \mathbf{2 , 2 9} \mathrm{cm} \text { atgal. } \\
\text { Keliai pakrypę } \mathbf{7 , 4 5} \mathrm{cm} \text { ị priekị }\end{array}$ & 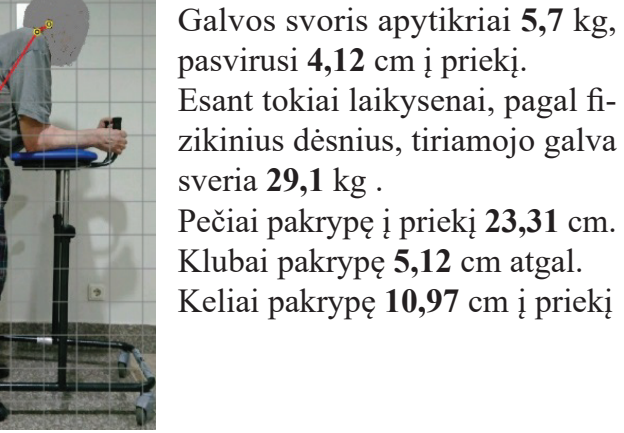 \\
\hline
\end{tabular}

9 lentelè. Judesio amplitudès vertinimas goniometru I ir II testavimo metu A1, A2-tiriamieji; D-dešinè; K-kairè; I-II testavimas; ${ }^{*} p<0,05$.

\begin{tabular}{|c|c|c|c|c|c|c|c|c|c|c|c|c|c|c|c|c|c|c|c|c|c|c|c|c|c|c|c|c|}
\hline \multirow{4}{*}{ 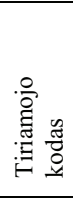 } & \multicolumn{12}{|c|}{ Šlaunis } & \multicolumn{8}{|c|}{ Blauzda } & \multicolumn{8}{|c|}{ Péda } \\
\hline & \multicolumn{4}{|c|}{ lenkimas } & \multicolumn{4}{|c|}{ tiesimas } & \multicolumn{4}{|c|}{ atitraukimas } & \multicolumn{4}{|c|}{ lenkimas } & \multicolumn{4}{|c|}{ tiesimas } & \multicolumn{4}{|c|}{ lenkimas } & \multicolumn{4}{|c|}{ tiesimas } \\
\hline & $\mathrm{D}$ & D & $\mathrm{K}$ & $\mathbf{K}$ & D & D & K & $\mathbf{K}$ & $\mathrm{D}$ & D & $\mathrm{K}$ & K & D & D & $\mathrm{K}$ & $\mathbf{K}$ & $\mathrm{D}$ & D & K & $\mathbf{K}$ & $\mathrm{D}$ & D & $\mathrm{K}$ & $\mathrm{K}$ & $\mathrm{D}$ & D & K & $\mathrm{K}$ \\
\hline & I & II & I & II & I & II & I & II & I & II & I & II & I & II & I & II & I & II & I & II & I & II & I & II & I & II & I & II \\
\hline $\mathrm{A} 1$ & 105 & $110^{*}$ & 100 & 100 & 5 & $10^{*}$ & 5 & $15^{*}$ & 15 & 35* & 10 & $35^{*}$ & 110 & $125^{*}$ & 120 & $125^{*}$ & -5 & 0* & -5 & 0* & 20 & $25^{*}$ & 20 & 20 & 10 & $12 *$ & 8 & 10 \\
\hline A2 & 60 & $85^{*}$ & 70 & $95^{*}$ & 15 & $20^{*}$ & 10 & 10 & 30 & 30 & 20 & 20 & 110 & $120^{*}$ & 120 & 120 & 0 & O & 0 & 0 & 25 & 30* & 30 & 30 & 15 & 15 & 10 & 10 \\
\hline
\end{tabular}


iš šono, nustatytas pečiu pakrypimo i priekị sumažèjimas $4,95 \mathrm{~cm}$, klubu pakrypimo atgal padidejjimas $3 \mathrm{~cm}$, kelių pakrypimo ị priekị sumažèjimas 3,27 centimetro ( 8 lentelè).

Kai kurie tiriamojo parametrai, palyginti tyrimo pradžioje ir po dviejų savaičių, regresavo, nes antrojo tyrimo metu tiriamasis buvo irzlus, nepatenkintas, slydo jo kojos, nors tą pačią avalynę dèvejjo pirmojo tyrimo bei dinaminių ir funkcinių treniruočių metu.

Judesių amplitudè buvo vertinta goniometru, pagal kineziterapeuto komandą atliekant aktyvius judesius. I ir II testavimo metu gauti rezultatai parodyti 9 lentelèje. Po dviejų savaičių kineziterapijos procedūrų ir eisenos treniravimo EIK treniruokliu, abiejų tiriamujų judesio amplitudè pagerejjo nevienodai. Abiejų tiriamujų pagerejjo dešinès šlaunies lenkimas, kairès blauzdos lenkimas ir dešinès pèdos teisimas $(\mathrm{p}<0.05)$, o kiti tirti judesiai - individualiai. A1 tiriamojo pagerėjo kairès šlaunies tiesimas, dešinès ir kairès šlaunies atitraukimas, kairès blauzdos lenkimas ir dešinès pèdos tiesimas ( $p<0,05), A 2$ pagerèjo kairès šlaunies lenkimas ( $p<0.05)$.

Tik A1 ir A2 tiriamieji buvo pajègūs eiti su treniruokliu EIK, ejimo procesas buvo filmuojamas, judesių amplitudès vertinamos vaizdo analizès programa Kinovea. A1 tiriamojo judesių amplitudès vertinimo rezultatai pateikiami 10-11 lentelèse. Antrojo filmavimo metu atlikti matavimai parodè, kad tiriamojo nugara daugiau atlošta, dešinès kojos atramos metu matoma didesnè tiesimo amplitudè per čiurnos sąnarị (geresnis kulno kontaktas); tiriamojo nugara daugiau atlošta, amortizacijos fazès metu dešinè koja per kelio sąnarị ištiesiama 50 proc. tiesiau, nei per I filmavimą. Dešinès kojos atsispyrimo fazès I ir II filmavimo duomenys nesiskiria. Tiriamojo judesiai neryškūs kulno atramos ir amortizacijos fazèse, todèl kairès kojos amortizacijos fazès

10 lentelè. A1 judesių amplitudè einat (vaizdas iš dešinès)

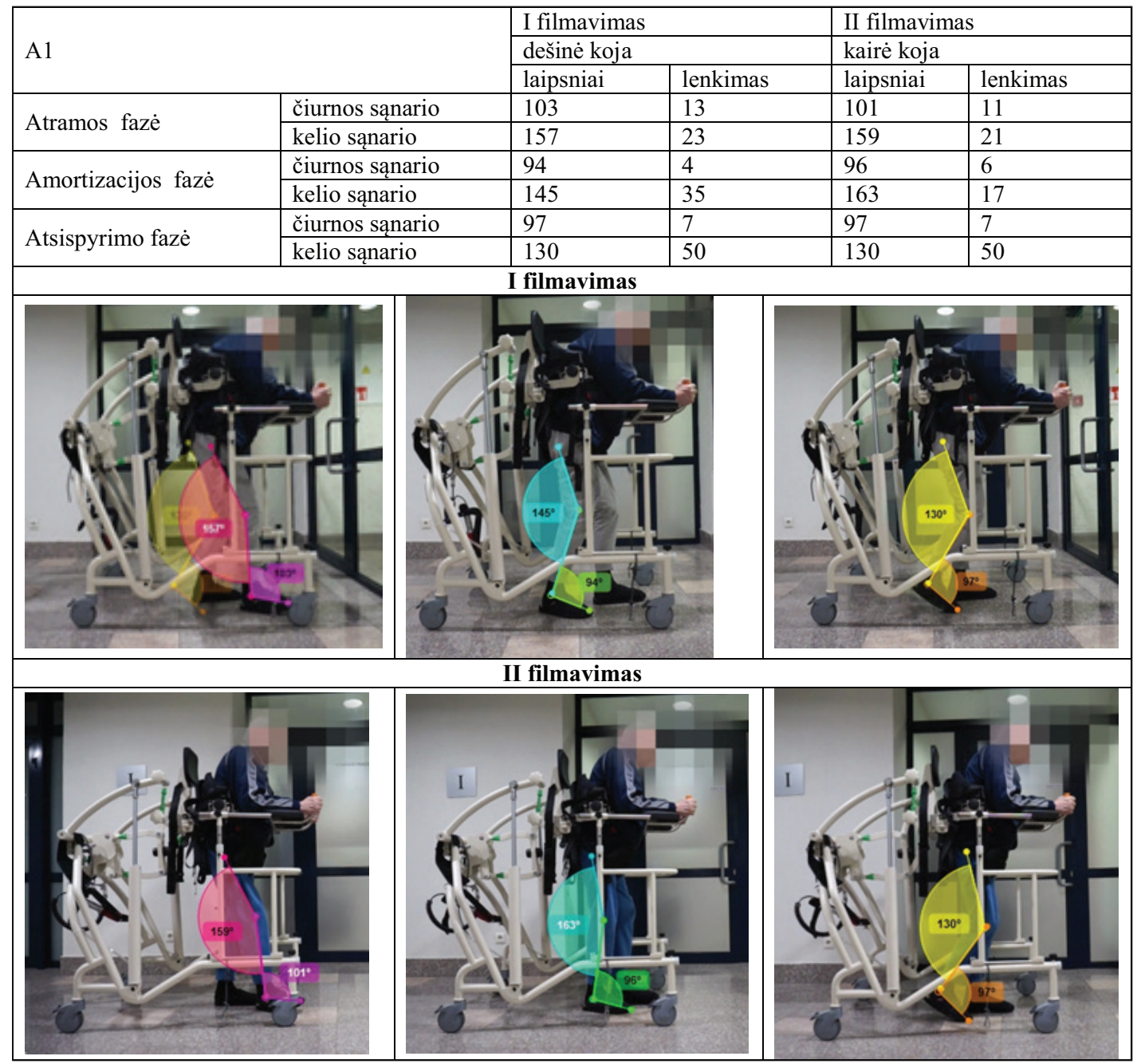


11 lentelè. A2 judesių amplitudè einat (vaizdas iš priekio)

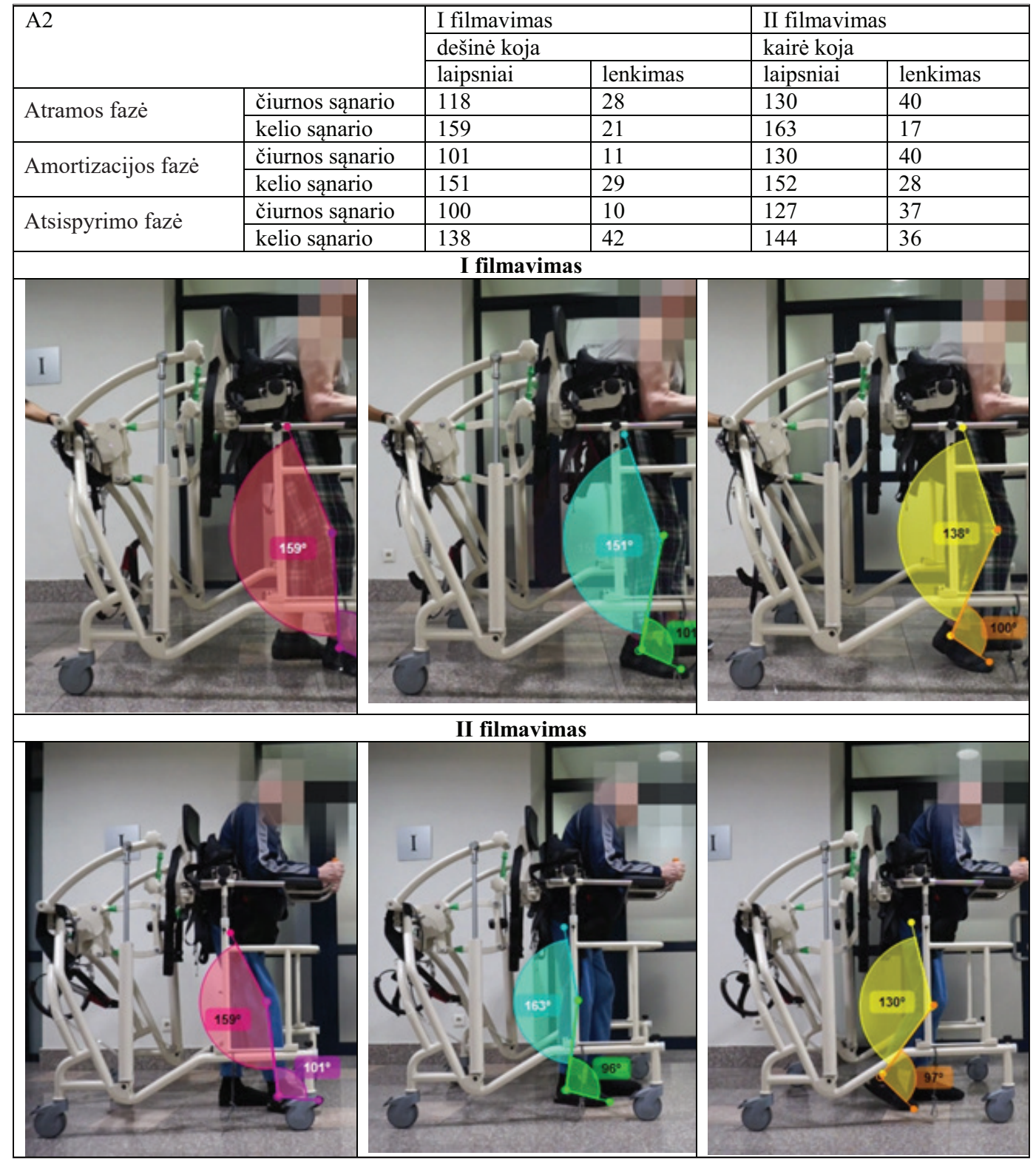

12 lentelè. Tiriamųjų raumenų jègos pokyčiai $(\mathrm{kg})$

\begin{tabular}{|c|c|c|c|c|c|c|c|c|}
\hline \multirow{3}{*}{ Raumuo (lot.) } & \multicolumn{4}{|c|}{ A1 tiriamojo } & \multicolumn{4}{|c|}{ A2 tiriamojo } \\
\hline & \multicolumn{2}{|c|}{ I vertinimas } & \multicolumn{2}{|c|}{ II vertinimas } & \multicolumn{2}{|c|}{ I vertinimas } & \multicolumn{2}{|c|}{ II vertinimas } \\
\hline & kairè & dešinė & kairè & dešiné & kairè & dešinè & kairè & dešinè \\
\hline Rectus femoris & 7,2 & 6,6 & 9,8 & 8 & 10,2 & 8,4 & 11 & 9 \\
\hline Gluteus maximus & 5,8 & 5,1 & 6,1 & 5,5 & 3,6 & 5,4 & 8 & 8,1 \\
\hline Gluteus medius & 4,9 & 5 & 8 & 4,9 & 6,8 & 6,5 & 7,9 & 9,5 \\
\hline Biceps femoris & 7,5 & 5,9 & 7,5 & 9,1 & 7,2 & 7 & 9,3 & 9,5 \\
\hline Tensor fasciae latae & 6,9 & 7,2 & 7,9 & 8,5 & 7,6 & 6,2 & 8 & 9,4 \\
\hline Tibialis anterior & 7,4 & 7,5 & 7,9 & 8,5 & 6,6 & 6,8 & 6,9 & 7,5 \\
\hline Gastrocnemius & 8,9 & 10 & 9 & 10 & 5 & 6,4 & 9 & 7 \\
\hline
\end{tabular}


duomenys I ir II filmavimų metu buvo labai panašūs arba vienodi. Atsispyrimo fazès metu kairè koja per kelio sąnarị buvo labiau ištiesta ir nuo I filmavimo skyrèsi 17 laipsnių.

A2 vertinant filmuotą eisenos medžiagą (9 lentelè) II filmavimo atramos fazès metu, stebimos padidejosios tiriamojo dešinès kojos blauzdos tiesimo amplitudès, tiesesnè nugara. Pastebèta didesnè pėdos išorinè rotacija (II filmavimo dieną tiriamasis buvo irzlus ir neịprastai silpnesnis dèl neaiškios priežasties). Atramos ir atsispyrimo fazių metu I ir II filmavimo rezultatai beveik nesiskyrè, išskyrus jau anksčiau minètą dèl neaiškios priežasties atsiradusią dešinès pẻdos išorinę rotaciją.

Tiriamujų raumenų jèga buvo vertinima rankiniu dinamometru. Jègos pokyčiai pateikiami 12 lentelèje. Tiriamojo A2 raumenų jèga po 2 savaičių padidejjo visose tirtose pozicijose. A1 po kineziterapijos ir ejimo treniruočių jèga nepadidejo kairès pusès m.gluteus medius ir dešinès $m$. biceps femoris; labiausiai padidèjo A1 kairès kojos $m$. rectus femoris raumens jèga (raumuo atsakingas už šlaunies lenkimą, blauzdos tiesimą) ir dešinès kojos $m$. biceps femoris jèga (šlaunies tiesimas, blauzdos lenkimas); tiriamojo A2 labiausiai padidèjo kairès ir dešinès pusès $m$. gluteus maximus jèga (raumuo atsakingas už šlaunies tiesimą), dešinès pusès $m$. gluteus medius (šlaunies atitraukimas, dubens stabilizavimas atramos fazès metu), abiejų kojų m. biceps femoris ir dešinès kojos $m$. tensor fasciae latae (šlaunies lenkimas, atitraukimas ir vidinè rotacija).

\section{Diskusija}

Naudojant eisenos treniruokli pacientams po insulto kartu su standartinèmis kineziterapijos procedūromis, pasiekiami geresni gydymo rezultatai, nei taikant kineziterapiją su paprastomis kompensacinėmis priemonėmis: ypač geriau lavinama pusiausvyra, ejjimo greitis, didejja savarankiškumas [14]. Kineziterapijos procedūrų po stuburo pažeidimų su specialia vaikštyne metu pagereja pacientų tolerancija fiziniam krūviui, užtikrinama saugi vertikalizacija ir ortostatinès reakcijos praeina greičiau, nei taikant standartines kineziterapines priemones. Iš visų tyrime taikytų reabilitacijos priemonių, raumenų tonusas mažejo ir didèjo liemens pusiausvyra geriausiai [15]. Mūsų tyrimo duomenimis, eisenos lavinimo užsiẻmimai su EIK ženkliai pagerino visų tiriamųjų nueinamą atstumą. Visų tiriamujų rezultatai kito nuosekliai. Ilgejjant einamam atstumui, ilgejo ir nueitas atstumas iki pirmo sustojimo, taip pat minimaliai, bet pastebimai mažèjo širdies susitraukimų dažnis, matuotas testo pabaigoje. Vis dèlto EIK taikymas labai priklauso nuo paciento fizinès ir funkcinès būklès, kognityvinių funkcijų, suvokimo, nusiteikimo ir pan. Asmenys, patyrę galvos smegenų insultą, ypač vyresnio amžiaus, gali būti labai jautrūs aplinkos sąlygoms ir kitoms aplinkybėms, todèl darbas su jais reikalauja labai daug žinių, patirties, pastangų ir pasiruošimo.

Sprendžiant dèl paciento galimybės naudotis eisenos treniruokliais, labai svarbus yra paciento ištyrimas ir funkcinių galimybių vertinimas - problemos įvertinimas ir jos pokyčio per tam tikrą laiką nustatymas. Tam tikslui pasitelkiami ìvairūs tyrimo ir vertinimo metodai - testai, skalès, indeksai ir t.t. [17-19].

Tyrime dalyvavę ekspertai, ịvertinę EIK pritaikomumo galimybes, pažymejjo, kad spalvą ir dizainą reikia tobulinti, nes sunku vaikštynę pritaikyti gyvenamojoje aplinkoje: , tobulinčiau dizaina, kad bütu smulkesnè ir lengviau būtu galima pritaikyti gyvenamojoje aplinkoje, kad niekur nekliūtu“";,, reikètu pakeisti dizaina (spalva) "; ,, modernesnis dizainas, mažesnis vaikštynès dydis, mažiau diržü “. İvertinę vaikštynès saugumą, pažymėjo, kad sẻdint neigaliojo vežimèlyje, sunku ją privežti prie treniruoklio: ,vaikštynę nepatogu privežti, todèl galima pamažinti vaikštynès apimtị “. Ekspertai iš dalies sutiko, kad minkštoji pakaba (liemenè) lengvai sujungiama su balnu ir šlaunų diržais, fiksatoriais lengvai sujungiama su vaikštynès korpusu, o minkštasis balnas lengvai užsegamas, patogus užsegtas ir nespaudžia. Apie EIK šlaunų diržus ir užsegimus nuomonès buvo įvairios, vieniems jie buvo patogūs, o kitiems reikètų supaprastinti, paminkštinti, užsegimo mechanizmus patobulinti: ,laisviau isimaunančio mechanizmo metalinès dalys (praslydimas), pompavimo mechanizmo lengvesnio (galètu büti automatizuota, bet neprisirišti prie elektros); galbūt reikia supaprastinti užsegimo mechanizmus, nes per daug sagčiu, kurias užsegti užtrunka nemažai laiko". Dèl vaikštynès EIK valdymo ekspertai pažymèjo: ,galètu būti kompaktiškesnè, lengviau valdoma pačio paciento; sunkoka inicijuoti èjima, sunkoka pajudetti iš vietos, bet eiti toliau buvo gan lengva“. Ivertinę galimybes taikyti papildomas priemones naudojantis vaikštyne EIK, ekspertai pažymejjo, kad patogiausia vaikštynèje stovint atlikti koordinacijos ir pusiausvyros bei stabilizavimo pratimus, patogu atlikti pratimus su pasipriešinimu ir einant su treniruokliu neribojami liemens judesiai. Ekspertai pasiūlè: ,truputị stabilizuoti pečiu juosta, nes norisi žiürèti i kojas ir automatiškai linkti i prieki (netaisyklinga laikysena) “. Dèl vaikštynès pritaikomumo kineziterapijos salëje ir namuose ekspertai pažymejjo, kad ji per didelè ir pateiké pasiūlymus: , mažinti matmenis “; ,,mažinti aparata, kad ji būtu galima naudoti bute“",,padaryti truputi kompaktiškesnę, kad labiau galètu büti taikoma ne tik sveikatos priežiūros istaigose".

Dviejų savaičių laikotarpis yra per trumpas pasiekti ženklesnių teigiamų rezultatų, o ypač tokios sunkios būklès ir vyresnio amžiaus pacientams, tačiau Posture screen ir Kinovea programų pagalba fiksuoti duomenys leidžia numatyti 
tolesnius teigiamus pacientų funkcinès būklès pokyčius, naudojantis treniruokliu EIK.

\section{Rekomendacijos}

Treniruoklio EIK kūrejjams, remiantis respondentų nuomonès tyrimo rezultatais, rekomenduojama patobulinti vaikštynès valdymo charakteristikas: vaikštynejje EIK turètų būtų lengvesnè ejjimo pradžia, lengvesnis valdymas einant, mažiau ribojamas žingsnio ilgis, lengvesnis stabdymas. Rekomenduojama mažinti vaikštynès dydį, didinti manevringumą ir supaprastinti diržų užsegimą, o kartu ir vaikštynès naudojimą.

Reabilitacijos paslaugų teikejjams rekomenduojama eisenos treniruoklį EIK tureti kiekvienoje gydymo įstaigoje, kur gydomi pacientai, turintys pusiausvyros ir eisenos sutrikimų. Po atlikto tyrimo galima teigti, jog eisenos treniruoklis EIK yra ne tik puiki alternatyva bègimo takeliui, bet ir daug kuo ji pranokstantis. Asmuo vertikalizuojamas, rankos ir kojos laisvos, gali judetti erdveje, artimai bendrauti su kitais žmonèmis, vaikščioti lauke, parke, stadione. Norėdamas išjudinti aparatą iš vietos, turi naudoti jègas, kontroliuoti judesius, o ne mechaniškai eiti ir žiūrèti ị sieną. EIK naudingas visiems pusiausvyros ir eisenos sutrikimų turintiems žmonèms. Vis dèlto užsiëmimai su eisenos treniruokliu EIK neturètų būti pagrindinè sveikatinimo priemonè, spastikos atveju ypač svarbus pastovus normalių sąnarių amplitudžių palaikymas.

\section{Išvados}

1. Tyrimo metu nustatyta, kad EIK turi didesnị teigiamą poveikị paciento liemens kontrolei (lyginant su paprasta aukšta vaikštyne), gerina liemens, pečiu juostos, nugaros raumenų funkciją, lavina èjimą, padeda atlikti taisyklingo ejjimo judesius, nes šiame treniruoklyje pacientai jaučiasi saugiau, neribojami jų viršutinès kūno dalies judesiai.

2. Nustatyta, kad tiriamieji, naudodamiesi aukšta vaikštyne, visą viršutinès kūno dalies svorį perkelia ant rankų ir jomis remiasi (užgula) i vaikštynès atramas, todèl negali išlaikyti kūno vertikaliai, svyra ị priekị, jaučiasi nesaugiai, o normalaus žingsnio formavimas yra pasunkèjęs.

3. Treniruoklis EIK pacientams, patyrusiems galvos smegenų insultą, yra palanki aktyvinimo ir vertikalizavimo priemonè, tačiau ji turi būti individualizuojama pagal paciento poreikius.

\section{DE்KOJAME KOLEGOMS}

Už pagalbą atliekant tyrimus - kineziterapeutems Irenai Petraitienei, Rui Wang ir Kristinai Žukienei;

už treniruoklį EIK - UAB VILDOMA komandai - direktoriui Virginijui Kregždei, Vidai Adomaitienei, Valerijui Denisovui.

\section{Literatūra}

1. Žukauskienė M. Kineziterapeutų profesinio rengimo turinio modeliavimas. Daktaro disertacija. Kaunas: VDU, 2011.

2. Asanuma $\mathrm{H}$, Keller A. Neurological basis of motorlearning and memory. Concepts Neurosci, 1991;2:1-30.

3. Hesse S, Uhlenbrock D. A mechanised gait trainer for restoration of gait. J Rehabil Res Dev 2000;37(6):701-708

4. Hesse S, Schmidt H, Werner C, Bardeleben A. Upper and lower extremity robotic devices for rehabilitation and for studying motor control. Curr Opin Neurol 2003;16(6):705-10. https://doi.org/10.1097/00019052-200312000-00010

5. Gait trainer EIK. www.eik-lt.eu.

6. Jamontaite IE, Venskaitis R, Juocevičius A. Effectiveness of physiotherapy using gait trainer after stroke. J Rehabil Med 2013;45(9):973-974.

7. Juocevičius A, Venskaitis R, Jamontaitè IE, Valiulis A. Reabilitacijos efektyvumas naudojant eisenos treniruoklį. Gerontologija, 2012;13(1):200-204.

8. Gibavičiūtè K, Venskaitis R, Jamontaite IE, Juocevičius A, Adomavičiūtè G. Skirtingų eisenos lavinimo priemonių taikymo efektyvumas pusiausvyrai ir eisenai. Gerontologija, 2014;15(4):232-238 .

9. Folstein MF, Folstein SE, McHugh PR. Mini-mental state: a practical method for grading the cognitive state of patients for the clinician. J Psychiat Res 1975;12:189-198.

https://doi.org/10.1016/0022-3956(75)90026-6

10. Stepanavičius Ž, Adomaitienè V. Bendrujų kognityvinių funkcijų vertinimo skalių reikšmè lengvo kognityvinio sutrikimo vertinimui ir Alzheimerio ligos prognozei. Sveikatos mokslai, 2012;22(5):137-140.

11. Pocienè M. Kineziterapijoje taikomi funkciniai testai. Mokomoji knyga. Kaunas: Vitae Litera, 2013; 51.

12. Delsys Trigno ${ }^{\mathrm{TM}}$ wireless EMG system. Moving Research Forward. http://www.jalimedical.com/delsys-trigno-wirelessemg-system.html

13. Valeckas D. Kramtymo raumenų elektromiografinio aktyvumo ivvertinimo metodu tyrimas. Baigiamasis magistro projektas. Kaunas, KTU, 2016.

14. Pohl M,Werner C, Holzgraefe M, Kroczek G, Mehrholz J,Wingendorf I, H olig G, Koch R \& Hesse S. Repetitive locomotor training and physiotherapy improve walking and basic activities of daily living after stroke: A single-blind, randomised multi-centre trial (Deutsche Gangtrainerstudie, DEGAS). Clinical Rehabilitation 2007; 1:17-27.

15. Jamontaitè E., Cirtautas A. Kineziterapijos procedūrų poveikis pacientų pusiausvyrai po galvos smegenų kraujotakos sutikimų. Sveikatos mokslai, 2004; 1:29-32.

16. Skučas K, Satkunskienė D. Unikalios reabilitacinės vaikštynès, skirtos specialiujų poreikių asmenims, poveikio raumenų aktyvumui, kūno pusiausvyrai ir èjimui vertinimas bei tobulinimas. Mokslinių tyrimų ir eksperimentinės plètros paslaugų ataskaita. Kaunas, Lietuvos sporto universitetas, 2013. 
17. Wade DT. Measurement in neurological rehabilitation. Oxford University Press, 1992.

18. Porter SB. Tidy's physiotherapy. Elsevier Helth Sciences 2003.

19. Белова АН. Нейрореабилитация: руководство для врачей. Москва: Антидор, 2002:736.

\section{POSSIBILITIES OF USING THE GAIT TRAINER EIK FOR POST STROKE ELDERLIES \\ M. Žukauskienė, L. Samsonienė}

Keywords: gait trainer, gait, posture, stroke, rehabilitation. Summary

The most important feature of the trainers is versatility, reliability and a wide range for use. The article discusses the applicability of the gait trainer EIK and the possibilities of using it for elderly people with disabilities. The aim of the study: to evaluate the possibilities of using the gait trainer EIK for persons after cerebrovascular disorders and to provide practical recommendations. Qualitative and quantitative research methods applied in the research: expert survey, analysis of medical documents; testing (goniome- try, assessment of muscle strength, 10 m walking; 6 min walking tests, etc.)); filming, photography, statistical data analysis. Results of the study: gait training sessions with EIK significantly improved the walking distance of all subjects $(p<0.05)$. The results of all subjects varied consistently. As the walking distance increased, the distance to the first stop also increased. Conclusions: The gait trainer EIK had a greater positive effect on patient trunk control, improved trunk, shoulder, back muscle function, developed patient gait, helped perform correct gait movements, patients felled safer and had unrestricted upper body movements. The gait trainer EIK is a positive activation and virtualization tool for stroke patients, but this tool must be purposefully individualized according to the patient's needs and abilities.

Correspondence to: laimute@samsonai.lt

Gauta 2020-12-16 